\title{
AC 2012-3807: EXPERIENCE TEACHING A GRADUATE RESEARCH METHODS COURSE
}

\section{Dr. Wayne W. Walter, Rochester Institute of Technology}

Wayne Walter is a professor of mechanical engineering at the Rochester Institute of Technology (RIT). He received his B.S. in marine engineering from SUNY Maritime College, his M.S. in mechanical engineering from Clarkson University, and his Ph.D. in mechanics from Rensselaer Polytechnic Institute. Walter has worked for the U.S. Army, Rochester Products and Delco Products divisions of General Motors, and Xerox, and is a registered Professional Engineer (P.E.) in New York state. He has 35 years experience teaching design related courses, and has developed expertise in the areas of robotics, and micro-robotics. $\mathrm{He}$ is currently working on the locomotion of micro-robots with micro-sensors and actuators, and on artificial muscles using electroactive polymers. 


\section{Experience Teaching a Graduate Research Methods Course}

The Research Methods course is designed for dual-degree mechanical engineering students wishing to change from a non-thesis, course only, Bachelor of Science/Master of Engineering (BS/MEng) program to a research-based Bachelor of Science/ Master of Science (BS/MS) program where a thesis is required. The course covers research tools that these students will need including: conducting reviews of technical papers, annotating technical papers, conducting a literature search, creating bibliographical citations, interviewing prospective faculty thesis advisors, ethics in engineering research, understanding the societal context of their research, and communicating research results, among others. After interviewing faculty, students decide on a thesis advisor and topic area. The main deliverable of the course is a preliminary thesis proposal consisting of an abstract, literature search, statement of work, and a timeline to complete their program. The evolution and development of the course, and experiences with students will be discussed in this paper, along with recommendations for individuals wishing to try such a course format.

\section{Introduction}

The Research Methods course evolved from restructuring the graduate program in 2001 initiated by a new department head joining the Department of Mechanical Engineering. At that time, the graduate program offered a thesis only BS/MS (and MS option for those who had already completed their BS degree), and had done so for the past thirty years. Over the years, a large number students accepted into the program were not research oriented, and were more focused on getting to work in industry in the shortest possible time. Many of these students completed their coursework, and accepted a job before completing their thesis, planning to finish it in the evenings and on weekends. For many, this never happened due to job and family responsibilities. It became apparent that once the student stepped off campus, the probability of finishing their thesis went to almost zero. As a result, resources allocated to their projects were wasted, and some funded projects were put at risk. The graduate program was restructured by the new department head to offer a non-thesis option Master of Engineeering (MEng) program for the majority of students in a dual-degree BS/MEng program (and MEng format for those who already were BS graduates), and a thesis option for a minority of students in a research-based BS/MS program (and MS form for those who already were BS graduates). Precious resources that were previously spread thinly over the entire graduate student population could now be better utilized by a few students in the MS programs. The "bar was raised" on the research level and expected quality of theses. Students applying to the graduate program were put into the nonthesis option programs by default, and those who wanted to change their status were expected to find a thesis advisor and topic, form a thesis committee, and prepare a thesis proposal and have it approved by their committee, before admission to the MS programs. The Research Methods course is specifically designed for students enrolled in the dual degree BS/MEng program offered through the department who would like to change their status to BS/MS. The course introduces students to research tools in mechanical engineering. A primary focus of the course is on conducting critical reviews of research literature, preparing a formal thesis proposal, and initiating background research on a thesis topic. At the conclusion of the course, students are expected to submit a formal thesis proposal, literature review, and plan of study for the 
completion of their Master of Science degree, and present their proposal to the class, the department head, and instructor. In a subsequent quarter, students refine their proposal and present it to their thesis committee for approval. At that point, their status is changed to MS, and they can register for thesis credit.

\section{Course Philosophy}

This course addresses the Mechanical Engineering Program Objective to prepare some of our graduates to enter graduate programs and succeed in obtaining graduate degrees at the Masters and/or PhD level. The MS degree program in mechanical engineering is focused on enabling a research-oriented career path for those of our students who are so inclined. Some non-dual degree MEng students wishing to change their status to MS also take the course to help them put together a successful proposal.

Students enrolled in this course are expected to perform work independently, with minimal guidance, and with utmost attention to professional standards and conduct. Students taking this course will be expected to perform at the level of a practicing BS mechanical engineer, even though students enrolled in the course are actually working concurrently toward their BS and MS degrees.

Students should plan to spend at least three hours outside of class for every hour spent inside of class. Since the class meets nominally four hours per week, students should set aside at least 12 hours in their work schedule every week for this course. There is a good deal of reading, and writing for this course. Slow readers and writers may need to spend more time than this, to meet the level of expected performance. While this will be a demanding class, at its successful conclusion, students should expect to:

1. Be well prepared to conduct MS level research in the broad field of mechanical engineering.

2. Identify a thesis advisor, and topic for their thesis, along with a working title.

3. Submit a thesis proposal and statement of work, with approval from their advisor, to the department for review and approval.

4. Prepare an academic curriculum vitae of courses to complete their degree

5. Prepare a schedule for completion of their degree.

6. Complete a preliminary literature review as a first start on their thesis.

\section{Topics Covered and Course Deliverables}

Topics covered include:

- How to learn from the literature

Conducting reviews of technical papers

Annotating technical papers

Conducting a literature search

Creating bibliographical citations 
- Where does the student's work fit in context?

Interviewing prospective faculty thesis advisors

Conducting background research on a faculty advisor

Understanding contemporary issues in a field research

Understanding the global and societal context of one's research

- Shaping one's future.

Writing a thesis proposal

Writing a statement of work

Writing a literature review

Preparing a schedule and timeline for one's research and degree

- Conducting research

Ethics in engineering research

Conducting experimental research

Conducting computational research

Conducting theoretical research

- Communicating research

Sharing ideas for research to a potential sponsor

Creating technical documents

Preparing and presenting a persuasive thesis proposal

Writing and defending a compelling thesis

Preparing an academic curriculum vitae

Students are expected to read 400 pages in an assigned text. The course recently began using the text [1] Scientific Writing and Communication: Papers, Proposals, and Presentations, by Angelika H. Hofmann, Oxford University Press, after the previous text [2] by Perelman went out of print. The Hofmann text covers such basic writing mechanics as word choice and word location, sentence structure, and paragraph organization before moving into citations, figures and tables, and manuscript and proposal planning and organizational strategies. Guidance for composing scientific documents and presentations then follows. Other materials are provided by the course instructor. Students are asked to complete on-line quizzes on the reading. Soon after the course begins, the engineering reference librarian makes a presentation about the databases available to the students for their literature review. She also introduces the students to the EndNote Bibliographic software, and how it can be used to compile a bibliography in the style of their choice. After they have decided on a thesis advisor and a topic, which may require them to seek out and interview potential faculty advisors, they meet with the reference librarian again in a one-on-one mode to sharpen their focus on the databases that are most appropriate for their thesis project.

When the course was initially conceived, students were asked to locate and review thirty citations appropriate to their topic, and to write one-page reviews of twenty of these in "four-part format." The four-part format consists of a summary of the paper in their own words (not the abstract of the paper), what is noteworthy about the paper (i.e. methodology, design of test 
apparatus, etc.), the strengths and weaknesses of the paper (what it does well, and what it lacks or fails to do), and how the paper will be useful to their thesis effort. The one-page reviews are combined later into an integrated narrative in paragraph form for the final version of their proposal. The narrative can also be expanded into the literature review chapter of their thesis draft. Completing twenty one-page reviews in a ten week quarter proved to be too ambitious for even the best students in the class. This has recently been reduced this to a review of twenty citations, the best ten of which should be reviewed in four-part format in a multiple revisions as follows:

- First draft of proposal: first draft versions of the Abstract, Statement of Work (with specific deliverables), Timeline to Complete their MS Program, and first draft of Literature Review to include three (3) of the best articles using the four-part format.

- Second draft of proposal: updated versions of the Abstract, Statement of Work (with specific deliverables), Timeline to Complete their MS Program, and second draft of Literature Review to include five (5) of the best articles using the four-part format.

- Third draft of proposal: updated versions of the Abstract, Statement of Work (with specific deliverables), Timeline to Complete their MS Program, and third draft of Literature Review to include eight (8) of the best articles using the four-part format.

- Fourth draft of proposal: updated versions of the Abstract, Statement of Work (with specific deliverables), Timeline to Complete their MS Program, and fourth draft of Literature Review to include ten (10) of the best articles using the four-part format.

- Fifth draft of proposal: final draft versions, for the course, of the Abstract, Statement of Work (with specific deliverables), Timeline to Complete their MS Program, and final draft of the Literature Review of the ten (10) articles reviewed in integrated paragraph narrative form, and a thesis proposal form signed by the thesis advisor indicating that they have read the proposal, and agree with it. Students are also asked to submit copies of the three best papers which they have marked up and annotated (filled-in the information "between the lines," derived equations, asked themselves questions, indicated what is noteworthy for their thesis, etc.). The hope here is that by doing this, they will start to raise the level of their expertise and knowledge on their topic, and begin to bridge the gap between their current expertise level and that typically assumed by the authors of the papers they are reviewing.

After each revision, students do a peer review of each other's draft and receive written comments from their peers and also from the course instructor. The students make a presentation of their fifth draft during exam week, Week 11, to the instructor and department head. Thesis advisors are requested by the students to attend. In preparation for this, students prepare their presentation, have it peer reviewed by the class, and practice presenting it to the class during Week 10. Presentations are typically 15-20 minutes and cover their topic, literature search, gaps identified in the literature, their research question that they will answer, statement of work, and their timeline to finish their program. This is followed by 15-10 minutes of questions, for a total of 30 minutes per student. Students report that the questions can be rather withering. The intent is to ascertain to what extent the candidate understands the literature, how committed they are to a 
thesis, how doable their plan is in the time they have available (about 12 months full-time after completing their courses), and how well they can think on their feet.

As a result of their presentation, the department head and instructor often decide that a candidate's proposal needs more work, i.e. they should further revise and update their proposal before it is presented to the candidate's thesis committee in a subsequent quarter. Acceptance of their proposal by their committee is required before the candidate can be admitted to the MS program, and before they can register for any portion of nine thesis credits. This can be a major issue if the candidate procrastinates until their courses are complete before presenting their revised proposal to their committee and getting it approved.

\section{Graduate Seminar}

The author hosts a weekly graduate seminar that complements the Research Methods course. All graduate students, BS/MEng, BS/MS, MEng, and MS students are expected to attend. The mission of the seminar series is to disseminate scholarly works to students, encourage them to pursue advanced degrees, and help them to choose cutting-edge research projects for theses. From a faculty perspective, a small mentoring group (led by the author), mentors junior faculty how to recruit graduate students and disseminate their research. The group is currently expanding the scope of junior faculty mentoring to include internal/external networking and promoting the national visibility/reputation of the university.

Faculty use the presentation as a recruiting opportunity, and mention specific openings they have available in their research group that they are seeking to fill, so it is a way to match students looking for an advisor and topic with faculty who are seeking students for their research program. Research Methods students looking for an advisor can follow up with a one-on-one meeting to talk about possible thesis topics, and whether funding is available to support them. Graduate students nearing completion of their theses are asked to present their work in order to practice for their upcoming thesis defense and to talk about their experiences and lessons learned.

\section{What works well, what needs improvement, and experience with students}

Some students come into the course already having chosen an advisor and a topic, and have a preliminary literature search completed. These students easily complete five revisions of their proposal in the 10 week quarter period. For those that do not, the first three to four weeks of the quarter are required to make those decisions after interviewing faculty. Completing five revisions of a quality proposal can be a challenge unless they are highly motivated. Getting the word out earlier to new dual degree students with research interests to begin thinking about an advisor and topic when they are first accepted into the program in year 3, may help smooth the process to a successful proposal for them. Occasionally students take the course when they are in their last quarter before they need to register for thesis credit, and have procrastinated about completing a proposal. These students will typically present their proposal to their committee during exam week (Week 11) after first presenting for practice to the Research Methods class, to the instructor, and to the department head. Of the three students that did this in the past fall quarter, two had their proposals accepted by their committee, but one did not and remained in the MEng 
program. Three or four students each year who have taken Research Methods will procrastinate on refining their proposal and presenting it to their committee until Week 11 of the quarter before they need to register for thesis credit. This rarely results in a quality proposal, and requires their committee to spend time reviewing it when they are the busiest grading exams.

Table 1 shows the history of the course since it was initiated in the spring quarter of the 2003/2004 academic year. Note that there are four designations for graduate students: Master of Engineering (EMEG 6), Master of Science (EMEM 6), and dual degree Bachelor of Science/Master of Engineering (EMEN) and Bachelor of Science/Master of Science (EMEB). In 2003/2004, the Master of Engineering program had yet to be offered for the first time, so students in the course were EMEB or EMEM 6 (i.e. Master of Science). The total number of students who took the course in each year (column 2) is broken down further in columns 3-6. The department typically has approximately 120 graduate students enrolled in Mechanical Engineering each year, so it is apparent only about 10-20\% of these pursue a thesis option. Most master's students are anxious to complete their graduate courses and get to work in industry as soon as possible. The small percentage who do pursue a thesis are research-oriented, and plan to go on for a $\mathrm{PhD}$ degree or go into an $\mathrm{R} \& \mathrm{D}$ position in industry. There are some thesis students (about five per year) who do not take Research Methods, and write a thesis proposal on the own. The course instructor is able to help to some of them in a one-on-one mode by reviewing their proposal and suggesting changes. Overall, based on data from the department office for the past seven years, between $40 \%$ to $89 \%$ of the students who took Research Methods each year went on to complete their thesis and earn their MS degree. See Table 1. Thesis completions in 2004/2005 were very low (40\%) when the MEng Program was initially offered, but rebounded in $2005 / 2006$, and have been on an improving trend since then. The balance of students $(60 \%$ in $2004 / 2005$ to $11 \%$ in 2009/2010) took the course and decided that a thesis was not for them. In this case they were able to use the course as a graduate elective in the Master of Engineering program. The course, together with the Graduate Seminar series, serves as a motivator for about half of research-oriented students to pursue a thesis option, but certainly not all. These students come to the realization that completing a thesis is a substantial commitment in time and effort, and involves working in an independent mode on a rather complex project with little, if any, direct supervision. It requires them to develop sufficient self-discipline and self-confidence to develop a timeline for themselves, and follow it. For some, this is too much of a challenge. The course seems to be working reasonably well recently for motivated research oriented students, and I recommend trying this format for those interested faculty. See Table 2 for course deliverables and timeline. 


\begin{tabular}{|c|c|c|c|c|c|}
\hline \multicolumn{6}{|c|}{ Table 1: Students That Complete a MS Thesis Option in Mechanical Engineering } \\
\hline \multicolumn{6}{|c|}{ EMEN - dual degree BS/MEng } \\
\hline \multicolumn{6}{|c|}{ EMEB - dual degree BS/MS } \\
\hline \multicolumn{6}{|c|}{ EMEG 6 - Master of Engineering (MEng) } \\
\hline \multicolumn{6}{|c|}{ EMEM 6 - Master of Science (MS) } \\
\hline \multicolumn{6}{|c|}{$*$,** Students are currently working on their theses, and have yet to complete them } \\
\hline \multicolumn{6}{|c|}{ *** First Year MEng Program Offered } \\
\hline Year & $\begin{array}{l}\text { \# of students } \\
\text { enrolled in } \\
\text { Research } \\
\text { Methods } \\
\text { (total) }\end{array}$ & $\begin{array}{c}\text { \# of EMEM } 6 \\
\text { students } \\
\text { enrolled in } \\
\text { Research } \\
\text { Methods }\end{array}$ & $\begin{array}{l}\text { \# of EMEG } 6 \\
\text { students } \\
\text { enrolled in } \\
\text { Research } \\
\text { Methods }\end{array}$ & $\begin{array}{c}\# \text { of } \\
\text { EMEN/EMEB } \\
\text { students } \\
\text { enrolled in } \\
\text { Research } \\
\text { Methods }\end{array}$ & $\begin{array}{c}\text { \# of students } \\
\text { who took } \\
\text { Research } \\
\text { Methods } \\
\text { that } \\
\text { completed } \\
\text { MS }\end{array}$ \\
\hline $2003 / 2004$ & 12 & 1 & 0 & 11 & $10(83 \%)$ \\
\hline $2004 / 2005^{* * *}$ & 10 & 0 & 0 & 10 & $4(40 \%)$ \\
\hline $2005 / 2006$ & 7 & 0 & 1 & 6 & $5(71 \%)$ \\
\hline $2006 / 2007$ & 9 & 0 & 1 & 8 & $5(56 \%)$ \\
\hline $2007 / 2008$ & 14 & 0 & 3 & 11 & $8(57 \%)$ \\
\hline $2008 / 2009$ & 23 & 3 & 9 & 11 & $15(65 \%)$ \\
\hline $2009 / 2010$ & 9 & 1 & 4 & 4 & $8(89 \%)$ \\
\hline $2010 / 2011$ & 17 & 2 & 2 & 13 & $1^{*}$ \\
\hline $2011 / 2012$ & 7 & 1 & 2 & 4 & $* *$ \\
\hline
\end{tabular}

\section{References}

1. Angelika H. Hofmann, Scientific Writing and Communication: Papers, Proposals, and Presentations, Oxford University Press.

2. Leslie C. Perelman, James Paradis, and Edward Barrett, The Mayfield Handbook of Technical and Scientific Writing, McGraw Hill, 1997. 


\begin{tabular}{|c|c|c|c|c|c|}
\hline Wk & Day & Date & Topic & Homework Due & Points \\
\hline \multirow[t]{2}{*}{1} & \multirow[t]{2}{*}{$\begin{array}{l}\text { Tue } \\
\text { sday }\end{array}$} & \multirow[t]{2}{*}{$\begin{array}{l}\text { 6- } \\
\text { Sep- } \\
11\end{array}$} & $\begin{array}{l}\text { Course introduction, objectives, } \\
\text { schedule, and deliverables. } \\
\text { Overview of a thesis. Outline, } \\
\text { scope of work, examples of prior } \\
\text { work. }\end{array}$ & \multirow[t]{2}{*}{$\begin{array}{l}\text { Submit background survey to } \\
\text { assist instructor with thesis } \\
\text { topic/advisor } \\
\text { recommendations. }\end{array}$} & \\
\hline & & & $\begin{array}{l}\text { Overview of faculty members' } \\
\text { research interests in M.E. } \\
\text { Discuss GRE Exam briefly. }\end{array}$ & & \\
\hline \multirow[t]{2}{*}{1} & \multirow[t]{2}{*}{$\begin{array}{l}\text { Thu } \\
\text { rsda } \\
\text { y }\end{array}$} & \multirow[t]{2}{*}{$\begin{array}{l}8- \\
\text { Sep- } \\
11\end{array}$} & \multirow{2}{*}{$\begin{array}{l}\text { Individual consultations with } \\
\text { each student to review interests } \\
\text { and identify potential faculty } \\
\text { advisors and thesis topics. } 25-30 \\
\text { minutes each. Attend Grad } \\
\text { Seminar 1-2 pm today. }\end{array}$} & $\begin{array}{l}\text { Participate in interviews with } \\
\text { faculty. Begin collecting } \\
\text { papers on topics of potential } \\
\text { interest. }\end{array}$ & \\
\hline & & & & $\begin{array}{l}\text { HW: Reading Assign. \#1: } \\
\text { Read Chap 1-6 (136 pages) of } \\
\text { Text. }\end{array}$ & \\
\hline \multirow[t]{2}{*}{2} & \multirow[t]{2}{*}{$\begin{array}{l}\text { Tue } \\
\text { sday }\end{array}$} & \multirow[t]{2}{*}{$\begin{array}{l}13- \\
\text { Sep- } \\
11\end{array}$} & \multirow[t]{2}{*}{$\begin{array}{l}\text { Individual Consultations } \\
\text { Continued. }\end{array}$} & $\begin{array}{l}\text { Participate in interviews with } \\
\text { faculty. Collect papers on } \\
\text { topics of potential interest. }\end{array}$ & \\
\hline & & & & $\begin{array}{l}\text { Complete on-line test related } \\
\text { to reading assignment } \# 1\end{array}$ & 50 \\
\hline \multirow[t]{2}{*}{2} & \multirow[t]{2}{*}{$\begin{array}{l}\text { Thu } \\
\text { rsda } \\
y\end{array}$} & \multirow[t]{2}{*}{$\begin{array}{l}15- \\
\text { Sep- } \\
11\end{array}$} & \multirow{2}{*}{$\begin{array}{l}\text { Former ME MS student presents } \\
\text { his thesis proposal and oral } \\
\text { presentation to his thesis } \\
\text { committee. Discuss reading } \\
\text { Assignment \#1. Discuss } \\
\text { preparation for the GRE Exam } \\
\text { to be given at RIT. All MS } \\
\text { students must take it. Attend } \\
\text { Grad Seminar 1-2pm today. }\end{array}$} & $\begin{array}{l}\text { Participate in interviews with } \\
\text { faculty. Collect papers on } \\
\text { topics of potential interest. }\end{array}$ & \\
\hline & & & & $\begin{array}{l}\text { HW: Reading Assign. \#2: } \\
\text { Read Chap 7-9 (77 pages) of } \\
\text { Text. }\end{array}$ & \\
\hline \multirow[t]{2}{*}{3} & \multirow[t]{2}{*}{$\begin{array}{l}\text { Tue } \\
\text { sday }\end{array}$} & \multirow[t]{2}{*}{$\begin{array}{l}20- \\
\text { Sep- } \\
11\end{array}$} & $\begin{array}{l}\text { How to conduct a critical review } \\
\text { of a technical paper. How to } \\
\text { annotate and review a technical } \\
\text { paper. Discuss reviewing an } \\
\text { article using the } 4 \text { part format. } \\
\text { Discuss Reading Assign. \#2. }\end{array}$ & $\begin{array}{l}\text { Complete on-line test related } \\
\text { to reading assignment } \# 2\end{array}$ & 50 \\
\hline & & & $\begin{array}{l}\text { Understanding the context of } \\
\text { your research work. }\end{array}$ & Submit interview report \#1. & 50 \\
\hline 3 & $\begin{array}{l}\text { Thu } \\
\text { rsda } \\
\text { y }\end{array}$ & $\begin{array}{l}22- \\
\text { Sep- } \\
11\end{array}$ & $\begin{array}{l}\text { Hour 1: How to use the RIT } \\
\text { library. Guest visit by Linette } \\
\text { Koren, Engineering Reference } \\
\text { Librarian, RIT Library. }\end{array}$ & Submit interview report \#2. & 50 \\
\hline
\end{tabular}




\begin{tabular}{|c|c|c|c|c|c|}
\hline & & & $\begin{array}{l}\text { Hour 2: Class workshop on } \\
\text { performing a database search } \\
\text { and use of EndNote. Schedule to } \\
\text { meet with Linette for Thesis } \\
\text { Consult within } 2 \text { weeks! Attend } \\
\text { Grad Seminar 1-2pm today. }\end{array}$ & $\begin{array}{l}\text { Submit interview report \#3. } \\
\text { Make a tentative selection of } \\
\text { thesis advisor and topic } \\
\text { area. Continue to collect } \\
\text { papers on the topic likely to be } \\
\text { your thesis topic. }\end{array}$ & 50 \\
\hline 4 & $\begin{array}{l}\text { Tue } \\
\text { sday }\end{array}$ & $\begin{array}{l}27- \\
\text { Sep- } \\
11\end{array}$ & $\begin{array}{l}\text { Engineering reference librarian } \\
\text { returns to talk about EndNote } \\
\text { Web software. How to conduct } \\
\text { research on a faculty member or } \\
\text { researcher in your area. } \\
\text { Research the background of } \\
\text { your tentative advisor in detail } \\
\text { (Really drill down in his/her } \\
\text { interests and papers published)! } \\
\text { Select a paper of theirs to review } \\
\text { on } 10 / 12 \text { in class, and review it } \\
\text { as best you can in the } 4 \text { part } \\
\text { format for the } 10 / 11 \text { class (we'll } \\
\text { talk more about how to do this } \\
\text { properly in an upcoming class } \\
\text { on 10/6). }\end{array}$ & $\begin{array}{l}\text { HW: Reading Assign. \#3: } \\
\text { Read Chap 10-17 (133 pages) } \\
\text { of text. Review of selected } \\
\text { paper due at the } 10 / 11 \text { class. }\end{array}$ & \\
\hline 4 & $\begin{array}{l}\text { Thu } \\
\text { rsda } \\
\text { y }\end{array}$ & $\begin{array}{l}29- \\
\text { Sep- } \\
11\end{array}$ & $\begin{array}{l}\text { Individual consultations with } \\
\text { each student to review interests } \\
\text { and identify likely faculty } \\
\text { advisors and thesis topics. } 20-30 \\
\text { minutes each. Attend Grad } \\
\text { Seminar 1-2pm today. }\end{array}$ & $\begin{array}{l}\text { Complete on-line test related } \\
\text { to reading assignment \#3 }\end{array}$ & 50 \\
\hline 5 & $\begin{array}{l}\text { Tue } \\
\text { sday }\end{array}$ & $\begin{array}{l}4- \\
\text { Oct- } \\
11 \\
\end{array}$ & $\begin{array}{l}\text { Individual Consultations } \\
\text { Continued. }\end{array}$ & $\begin{array}{l}\text { HW: Reading Assign. \#4: } \\
\text { Read Chap 27-29 (69 pages) } \\
\text { of text. }\end{array}$ & \\
\hline 5 & $\begin{array}{l}\text { Thu } \\
\text { rsda } \\
\text { y }\end{array}$ & $\begin{array}{l}6- \\
\text { Oct- } \\
11\end{array}$ & $\begin{array}{l}\text { How to prepare an RIT Thesis } \\
\text { Proposal: (1) Proposal Form (2) } \\
\text { Statement of work and (3) } \\
\text { Literature Review using the } 4 \\
\text { part format, and (4) Abstract. } \\
\text { RIT ME Policies about thesis } \\
\text { proposals, committees, defense, } \\
\text { etc. }\end{array}$ & $\begin{array}{l}\text { Complete on-line test related } \\
\text { to reading assignment \#4. At } \\
\text { this point, you should have } \\
\text { confirmed a thesis advisor } \\
\text { and thesis topic, and } \\
\text { obtained at least } 5 \text { papers on } \\
\text { your topic. Write a first } \\
\text { draft of a Literature Review } \\
\text { of your first paper (best of } \\
\text { the five found so far) using } \\
\text { the } 4 \text { part format discussed } \\
\text { today in class. Bring this to } \\
\text { the next class. Now that your } \\
\text { advisor and topic is } \\
\text { confirmed, schedule a Thesis }\end{array}$ & \\
\hline
\end{tabular}




\begin{tabular}{|c|c|c|c|c|c|}
\hline & & & & $\begin{array}{l}\text { Consult with Librarian } \\
\text { Linette Koren, to be } \\
\text { completed by } 10 / 18 \text {. }\end{array}$ & \\
\hline 6 & $\begin{array}{l}\text { Tue } \\
\text { sday }\end{array}$ & $\begin{array}{l}11- \\
\text { Oct- } \\
11\end{array}$ & $\begin{array}{l}\text { Workshop : Writing a model } \\
\text { Literature Review, Abstract, } \\
\text { Statement of Work, and } \\
\text { Abstract. Proper Citations. } \\
\text { PEER REVIEW of your first } \\
\text { attempt at a review of an article. } \\
\text { Discuss Reading Assignments } \\
\text { \#3 \& \#4. Attend Grad Seminar } \\
\text { Today. }\end{array}$ & $\begin{array}{l}\text { HW: You should have at least } \\
\text { ten papers in your possession } \\
\text { by now. Submit bibliography } \\
\text { list of these } 10 \text {. Continue to } \\
\text { work on the Literature } \\
\text { Review. Discuss with your } \\
\text { advisor a suitable focused } \\
\text { topic, title, and continue work } \\
\text { on a Statement of Work. }\end{array}$ & 50 \\
\hline \multirow[t]{2}{*}{6} & $\begin{array}{l}\text { Thu } \\
\text { rsda } \\
\text { y }\end{array}$ & $\begin{array}{l}13- \\
\text { Oct- } \\
11\end{array}$ & $\begin{array}{l}\text { A typical timeline for } \\
\text { completion of an MS degree and } \\
\text { an MS Thesis. Using MS Project } \\
\text { to prepare a timeline (Gantt } \\
\text { Chart) and manage your efforts. }\end{array}$ & \multirow{2}{*}{$\begin{array}{l}\text { Submit first draft of thesis } \\
\text { proposal to include: Thesis } \\
\text { Proposal Form initialed by } \\
\text { Thesis Advisor, draft versions } \\
\text { of the Abstract, Thesis } \\
\text { Statement of Work, Timeline, } \\
\text { and 1st draft of Literature } \\
\text { Review to include three (3) of } \\
\text { the best articles of the ten } \\
\text { found so far using the } 4 \text { part } \\
\text { format (to be replaced by final } \\
\text { draft of Literature Review due } \\
\text { in Week 10). }\end{array}$} & \multirow[t]{2}{*}{100} \\
\hline & & & $\begin{array}{l}\text { Workshop on Revisions to your } \\
\text { Thesis Proposal and proper } \\
\text { citations. Attend Grad Seminar } \\
\text { 1-2pm today. }\end{array}$ & & \\
\hline \multirow[t]{2}{*}{7} & \multirow[t]{2}{*}{$\begin{array}{l}\text { Tue } \\
\text { sday }\end{array}$} & \multirow[t]{2}{*}{$\begin{array}{l}18- \\
\text { Oct- } \\
11\end{array}$} & $\begin{array}{l}\text { Weaving the one page article } \\
\text { reviews into an integrated } \\
\text { narrative that tells the story of } \\
\text { what has been done in the topic } \\
\text { area and who did it. A Four Step } \\
\text { Method to creating a literature } \\
\text { review narrative that could form } \\
\text { a chapter of your thesis draft. } \\
\text { What makes a good literature } \\
\text { review? Workshop time. }\end{array}$ & \multirow[t]{2}{*}{$\begin{array}{l}\text { By Today: Participate in a } \\
\text { "Thesis Consult" with Linette } \\
\text { Koren at Wallace Library. She } \\
\text { will help you identify the } \\
\text { databases that are likely to be } \\
\text { very useful in finding articles } \\
\text { related to your thesis topic } \\
\text { area. Hand in a copy of your } \\
\text { notes showing the task is } \\
\text { complete. }\end{array}$} & \multirow[t]{2}{*}{50} \\
\hline & & & $\begin{array}{l}\text { Proper citations and methods. } \\
\text { Issues of academic honesty, } \\
\text { plagiarism, and recognition of } \\
\text { the work of others. }\end{array}$ & & \\
\hline
\end{tabular}




\begin{tabular}{|c|c|c|c|c|c|}
\hline 7 & $\begin{array}{l}\text { Thu } \\
\text { rsda } \\
\text { y }\end{array}$ & $\begin{array}{l}20- \\
\text { Oct- } \\
11\end{array}$ & $\begin{array}{l}\text { Individual consultations with } \\
\text { each student as needed to firm } \\
\text { up thesis direction. } 25-30 \\
\text { minutes each. Attend Grad } \\
\text { Seminar 1-2pm today. }\end{array}$ & $\begin{array}{l}\text { Submit 2nd draft of thesis } \\
\text { proposal to include one page } \\
\text { reviews of five (5) relevant } \\
\text { articles, with appropriate } \\
\text { citations, analysis, and review } \\
\text { format. Include updated } \\
\text { Abstract, SOW, and Timeline. } \\
\text { Attach bibliography list of } \\
\text { articles collected so far. (Bring } \\
\text { this submittal to your } \\
\text { individual consultation) }\end{array}$ & 100 \\
\hline 8 & $\begin{array}{l}\text { Tue } \\
\text { sday }\end{array}$ & $\begin{array}{l}25- \\
\text { Oct- } \\
11\end{array}$ & $\begin{array}{l}\text { Individual Consultations } \\
\text { Continued. }\end{array}$ & $\begin{array}{l}\text { HW: Reading Assignment \#5: } \\
\text { Skim Chap 19-26 (122 pages) } \\
\text { in text on Proposals. Work on } \\
\text { literature review. }\end{array}$ & \\
\hline 8 & $\begin{array}{l}\text { Thu } \\
\text { rsda } \\
\text { y }\end{array}$ & $\begin{array}{l}27- \\
\text { Oct- } \\
11\end{array}$ & $\begin{array}{l}\text { Individual Consultations } \\
\text { Continued. Attend Grad } \\
\text { Seminar 1-2pm today. }\end{array}$ & $\begin{array}{l}\text { Bibliographic search and } \\
\text { database of at least } 20 \text { related } \\
\text { papers should be complete. } \\
\text { Submit at this time. Submit } \\
\text { 3rd draft of thesis proposal } \\
\text { to include one page reviews of } \\
\text { eight (8) relevant articles, with } \\
\text { appropriate citations, analysis, } \\
\text { and review format. Include } \\
\text { updated Abstract, SOW, and } \\
\text { Timeline. Attach bibliography } \\
\text { list of articles collected so far. }\end{array}$ & 50 \\
\hline 8 & $\begin{array}{l}\text { Frid } \\
\text { ay }\end{array}$ & $\begin{array}{l}28- \\
\text { Oct- } \\
11\end{array}$ & $\begin{array}{l}\text { If no thesis topic is identified, } \\
\text { or you decide not to pursue the } \\
\text { MS degree (stay with } \\
\text { BS/MEng), this is the time to } \\
\text { decide! }\end{array}$ & $\begin{array}{l}\text { Last Day to } \mathrm{W} \text { from the } \\
\text { Class. }\end{array}$ & \\
\hline 9 & $\begin{array}{l}\text { Tue } \\
\text { sday }\end{array}$ & $\begin{array}{l}1- \\
\text { Nov- } \\
11\end{array}$ & $\begin{array}{l}\text { Preparing a compelling } \\
\text { presentation to describe your } \\
\text { thesis to help you in your Week } \\
11 \text { presentation to the ME } \\
\text { department head. }\end{array}$ & $\begin{array}{l}\text { Work on literature review. } \\
\text { Look over Chap } 10 \text { in text as a } \\
\text { potential resource. }\end{array}$ & \\
\hline \multirow[t]{2}{*}{9} & \multirow[t]{2}{*}{$\begin{array}{l}\text { Thu } \\
\text { rsda } \\
\mathrm{y}\end{array}$} & \multirow[t]{2}{*}{$\begin{array}{l}3- \\
\text { Nov- } \\
11\end{array}$} & $\begin{array}{l}\text { Editing process and peer review } \\
\text { in class. } \\
\text { Discuss grant proposal writing } \\
\text { (Reading Assignment \#5) }\end{array}$ & \multirow{2}{*}{$\begin{array}{l}\text { Look over Chap } 10 \text { in text as } \\
\text { a potential resource. Submit } \\
\text { 4th draft of thesis proposal } \\
\text { to include one page reviews of } \\
\text { ten (10) relevant articles, with } \\
\text { appropriate citations, analysis, } \\
\text { and review format. Include } \\
\text { updated Abstract, SOW, and } \\
\text { Timeline. Attach bibliography }\end{array}$} & \multirow[t]{2}{*}{50} \\
\hline & & & $\begin{array}{l}\text { Attend Grad Seminar 1-2pm } \\
\text { today. }\end{array}$ & & \\
\hline
\end{tabular}




\begin{tabular}{|c|c|c|c|c|c|}
\hline & & & & list of articles collected so far. & \\
\hline 10 & $\begin{array}{l}\text { Tue } \\
\text { sday }\end{array}$ & $\begin{array}{l}8- \\
\text { Nov- } \\
11\end{array}$ & $\begin{array}{l}\text { Editing process and peer review } \\
\text { continued to finalize thesis } \\
\text { proposal. }\end{array}$ & $\begin{array}{l}\text { Prepare presentation of thesis } \\
\text { proposal for Week } 11 \\
\text { presentation }\end{array}$ & \\
\hline 10 & $\begin{array}{l}\text { Thu } \\
\text { rsda } \\
\text { y }\end{array}$ & $\begin{array}{l}10- \\
\text { Nov- } \\
11\end{array}$ & Discussion of Ethics in Research & $\begin{array}{l}\text { Final version of thesis } \\
\text { proposal (fifth draft) due } \\
\text { with Abstract, Statement of } \\
\text { Work, Timeline, and } \\
\text { Literature Review in } \\
\text { integrated narrative format } \\
\text { (estimated length } 10 \text { pages, } \\
\text { plus Bibliography of } 20 \\
\text { citations of articles). Include } \\
\text { your one-page reviews written } \\
\text { on the best } 10 \text { of these articles } \\
\text { in an appendix. A review } \\
\text { should include a succinct } \\
\text { summary of the article, } \\
\text { highlights of the main research } \\
\text { agenda (the problem, methods, } \\
\text { data, or conclusions), an } \\
\text { evaluation of deficiencies in } \\
\text { the article as well as what the } \\
\text { article does well, followed by } \\
\text { a discussion of how the article } \\
\text { relates to the student's thesis } \\
\text { (Four-part format). Identify } 3 \\
\text { very relevant papers of these } \\
\text { ten, and analyze these line-by- } \\
\text { line. Fill in work between the } \\
\text { lines, ie fill in the "blanks" } \\
\text { between the lines for these } \\
\text { three papers. Attach copy of } \\
\text { Thesis Proposal Form } \\
\text { (initialized by advisor that } \\
\text { they agree with it but it may } \\
\text { not be in final form for } \\
\text { presentation to your thesis } \\
\text { committee). Please include the } \\
\text { annotated copies of the three } \\
\text { best papers discussed above. }\end{array}$ & $\begin{array}{l}200 \\
\text { Final } \\
\text { Draft, } \\
50 \\
\text { form } \\
\text { signed } \\
\text { by } \\
\text { adv. }\end{array}$ \\
\hline
\end{tabular}




\begin{tabular}{|c|c|c|c|c|c|}
\hline 11 & $\begin{array}{l}\text { TB } \\
\text { D }\end{array}$ & $\begin{array}{l}\text { Exam } \\
\text { Week }\end{array}$ & $\begin{array}{l}20 \text { minute presentations on your } \\
\text { thesis proposal to Department } \\
\text { Head. Department Head will ask } \\
\text { probing questions regarding the } \\
\text { details of your proposal to see } \\
\text { how well you understand first } \\
\text { principles, how well you } \\
\text { understand the topic and what } \\
\text { has been done to date in it, how } \\
\text { your work will fill a void/gaps in } \\
\text { that work, and how committed } \\
\text { you are to this project. }\end{array}$ & $\begin{array}{l}\text { Thesis abstract, statement of } \\
\text { work, timeline, literature } \\
\text { review, and presentation. Be } \\
\text { prepared for challenging } \\
\text { questions. }\end{array}$ & 50 \\
\hline & & & & Total Points & 1000 \\
\hline
\end{tabular}

